\title{
The Ability of Math Teachers to Develop Higher- Order Thinking Tasks
}

\author{
Burhanuddin \& Sugiman \\ Universitas Negeri Yogyakarta, Yogyakarta, Indonesia
}

\begin{abstract}
This study aims to describe the ability of junior high school math teachers to develop higher-order thinking tasks in Kutai Timur district. The kind of research was a survey with documentation method. A number of respondents were 34 math teachers of junior high school which certified in Kutai Timur district. This research used a document check list as an instrument to collect data. The analyzed data were $\mathrm{C}_{1}$ (remember), $\mathrm{C}_{2}$ (understand), $\mathrm{C}_{3}$ (apply) which classified to lower-order thinking (LOT); and $\mathrm{C}_{4}$ (analyze), $\mathrm{C}_{5}$ (evaluate), and $\mathrm{C}_{6}$ (create) which classified to higher-order thinking (HOT). Based on this research, the ability of junior high school math teachers in Kutai Timur district to develop HOT tasks based on Bloom's revised taxonomy is very poor $(20.10 \%)$ which consists of $\mathrm{C}_{4} \mathbf{1 7 . 6 5 \%}$; $\mathrm{C}_{5} \mathbf{2 . 4 5 \%}$ and $\mathrm{C}_{6} \mathbf{0 . 0 0 \%}$.
\end{abstract}

Keywords-Math Teachers, Higher-Order Thinking Tasks;

\section{INTRODUCTION}

Nowadays many studies have reported that to face the challenges and developments of the modern age, it requires not only conceptual knowledge but also the skills of applying knowledge and thinking skills. In addition, partnership for $21^{\text {st }}$ century skills formulates some skills as $21^{\text {st- }}$ century skills. Some of the skills contained in the $21^{\text {st }}$-century skills include creativity, critical thinking skills and problemsolving. These skills are often known as the scope of higherorder thinking skills. The demand for the need for these skills has implications for the need to improve the quality of education [16]. Nowadays, the development of science and technology is advancing. This has an impact on life, including on education [9].

Teachers are part of improving the quality of learning. Teacher quality is a very important part of the progress of a country. Finland is a country that switches from a traditional agrarian industrial country to a developed country whose economy is supported by science-based technological innovation. The progress is due to teachers' quality factors that have been prepared as well as possible before they teach [11].

Teachers as professionals indeed have function, role, and position that are very important in achieving the vision of education 2025 which is to create a smart and competitive Indonesian people. In Permendiknas Number 16 Year 2007, teacher competences include pedagogic, personality, social, and professional competences [5]. One of the compe- tencies of teachers in pedagogic aspect is to organize assessment, process evaluation, and learning outcomes. With this competence, among others, can determine the aspects of process and learning outcomes that are important to be assessed and evaluated according to the characteristics of junior high school subjects.

In the implementation of education, assessment is a very important aspect (Retnawati, Hadi, and Nugraha, 2016). The assessment instruments used by teachers to examine the learners' learning outcomes in cognitive aspects are usually taken from various books or collections of exam questions. Facts in the field indicate that the tasks tend to test more the memory aspect. Many books present materials by inviting learners to learn actively, the presentation of a systematic concept, however, are sometimes ended with some questions which lack of experiencing higher thinking skills.

There are several factors that cause teachers rarely trained high-level issues, especially those that require reasoning. Among these are teachers have not been able to make their own questions that match the reasoning indicator. In addition, there are few references of reasoning problems developed that can be used directly in the learning process. Another factor is that there are still teachers who are reluctant to provide tasks that require a more equally difficult process of thinking because they will spend more time on the learning process [10]. Training learners to be skillful in higher-order thinking can be done by providing teachers with tasks that characterize higher-order thinking skills. To support that, teacher is unlikely to move material in the textbook but must look for more weighty referrals [4].

Higher order thinking (HOT) has been defined by many researchers. Thomas \& Thorne (2009) define higher level thinking as a complex thinking process more than just memorizing facts or retelling past events similarly to the information when people get it in the first time. Furthermore, Thomas \& Thorne (2009) states that higher level thinking takes thinking to higher level than restating the facts [12]. Higher level thinking requires something with the facts. We must understand the facts, infer from them, connect them to other facts and concepts, categorize them, manipulate them, put them together in new ways, and apply them as we seek new solutions to new problems. 
Meanwhile, Lewis and Smith (1993) argue that higher-order thinking occurs when a person takes new information and information stored in memory and interrelates and/or rearranges and extends this information to achieve a purpose or find possible answers in perplexing situations [16]. From their opinions of experts it can be concluded that higher order thinking (HOT) requires a more complex thinking process in dealing with the new situation or solve a problem.

Resnick (in Apino and Retnawati, 2017) revealed some of the characteristics of HOTS as follows: (1) nonalgorithmic, meaning that the action steps cannot be fully determined at the beginning; (2) tends to be complex, meaning that steps cannot be seen or predictable directly from a certain perspective; (3) often yields multiple solutions; (4) involves nuanced judgement and interpretations; (5) involves the application of multiple criteria, which are sometimes mutually contradictory; (6) often involves uncertainty; (7) involving self-regulation of the thinking process; (8) involves imposing meaning, such as discovered the structure of the irregularity; and (9) requires effortful. If examined closely, the general characteristics of HOTS above demonstrates the need for unusual thought processes or thinking that is more complex and requires an usual effort anyway [2].

Bloom's taxonomy is the basic for higher-order thinking [17]. Bloom's taxonomy used in this study is Bloom's revised taxonomy. This is because the levels found in higher-order thinking skills include part of Bloom's revised taxonomy. The cognitive processes contained in Bloom's revised taxonomy are remembering, understanding, applying, analyzing, evaluating, and creating [13]. Three cognitive processes that are considered as higher order or HOT are analyzing, evaluating, and creating [6].

Analyze involves breaking material into its constituent parts and determining how the parts are related to one another and to an overall structure. Objectives classified as analyze include learning to determine the relevant or important pieces of a message (differentiating), the ways in which the pieces of a message are organized (organizing), and the underlying purpose of the message (attributing).

Evaluate is defined as making judgements based on criteria and standards. The criteria most often used are quality, effectiveness, efficiency, and consistency. The category evaluate includes the cognitive processes of checking (judgements about the internal consistency) and critiquing (judgements based on external criteria). Create involves putting elements together to form a coherent or functional whole. The processes involves in create are geerally coordinated with the student's previous learning experiences. Create is associated with three cognitive processes: generating, planning, and producing [1].

\section{METHOD}

In accordance with the stated objectives, this study was included in the survey. This research focuses on efforts to reveal the ability of junior high school teachers in developing the HOT tasks. This study does not provide treatment to the subject.

The participants of this research is math teachers of junior high school in Kutai Timur district, which are 34 math teachers which certified. The method used is documentation.

Data of research result obtained from result of analysis to developed tasks by math teachers. The instrument of data collection used is check list. The HOT contents in tasks developed by teacher obtained through documentation method by analyzing each item based on HOT category on Bloom's revised taxonomy. After that calculated the percentage and then determine the criteria interpretation score of teacher's ability in developing HOT task as in Table I.

TABLE I. INTERPRETATION CRITERIA OF TEACHERS' ABILITY SCORES

\begin{tabular}{|c|c|c|}
\hline No & Percentage Interpretation & Criteria \\
\hline 1 & $\mathrm{X}>85 \%$ & Very good \\
\hline 2 & $70 \%<\mathrm{X} \leq 85 \%$ & Good \\
\hline 3 & $50<\mathrm{X} \leq 70 \%$ & Moderate \\
\hline 4 & $25 \%<\mathrm{X} \leq 50 \%$ & Poor \\
\hline 5 & $\mathrm{X} \leq 25 \%$ & Very poor \\
\hline
\end{tabular}

\section{RESULTS AND DISCUSSION}

The percentage trend of Bloom's revised taxonomy cognitive dimension of 204 tasks the teacher-made can be seen in Fig 1 .

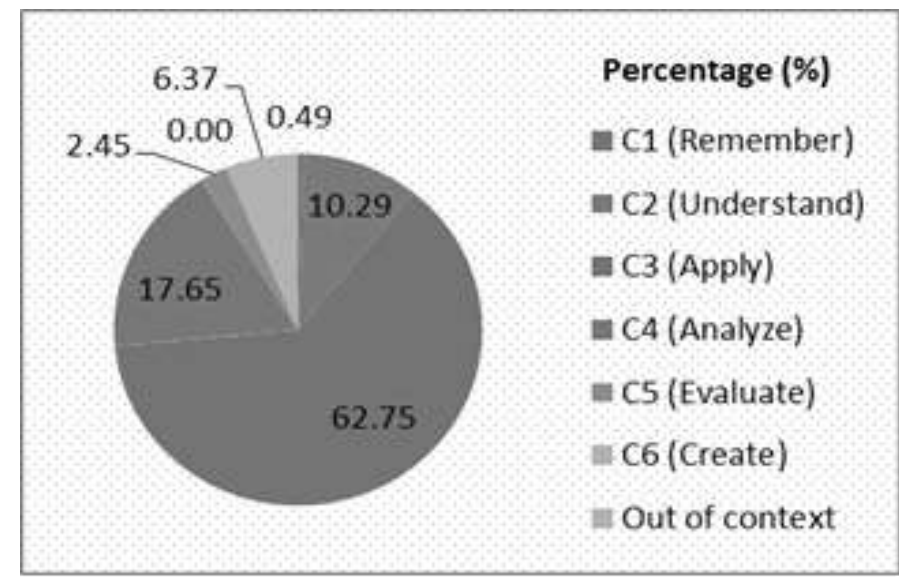

Fig 1. Trend percentage teacher-made of tasks 
The tasks developed by junior high school math teachers in Kutai Timur regency are still very poor at $20.10 \%$. This shows that the ability of math teachers in developing the tasks of HOT was still dominated by the element of lower order thinking. The following an example of HOT tasks that teachers can be develop. The HOT tasks at the level of analysis ability ( 44$)$ developed by the math teacher can be seen in Fig 2.The task on Fig 2 seems easy to solve it, but if students careless most likely students will answer wrongly. Students will assume that the matter is a simple comparative form of value, whereas the ratio of the value is stratified. Therefore it is necessary to have the ability to analyze the task as the answer in Fig 2. Thus at cognitive level C4, generally the information contained in the problem is not enough to solve the problem. So it takes different information to help solve the problem. The HOT task on the level of evaluation ability (C5) developed by the teacher can be seen in Fig 2 .

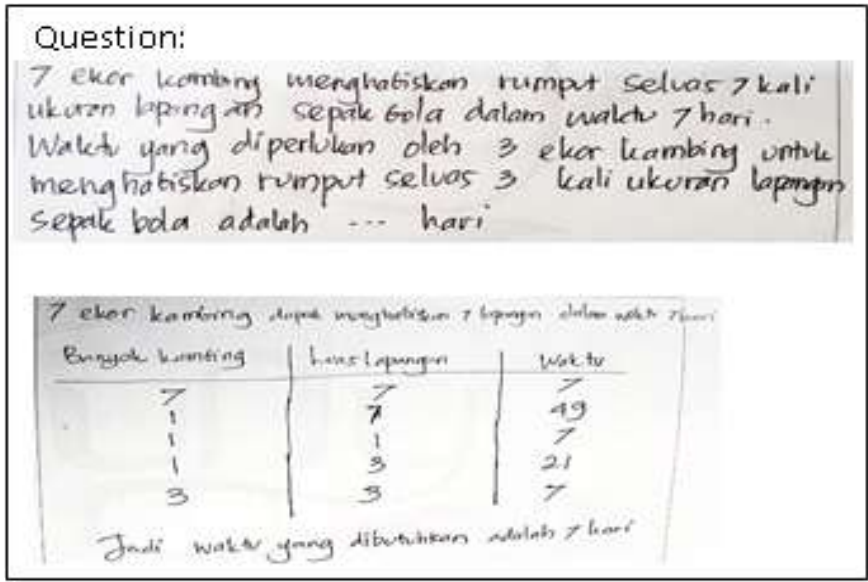

Fig 2. HOT task type $\mathrm{C}_{4}$ made by teacher

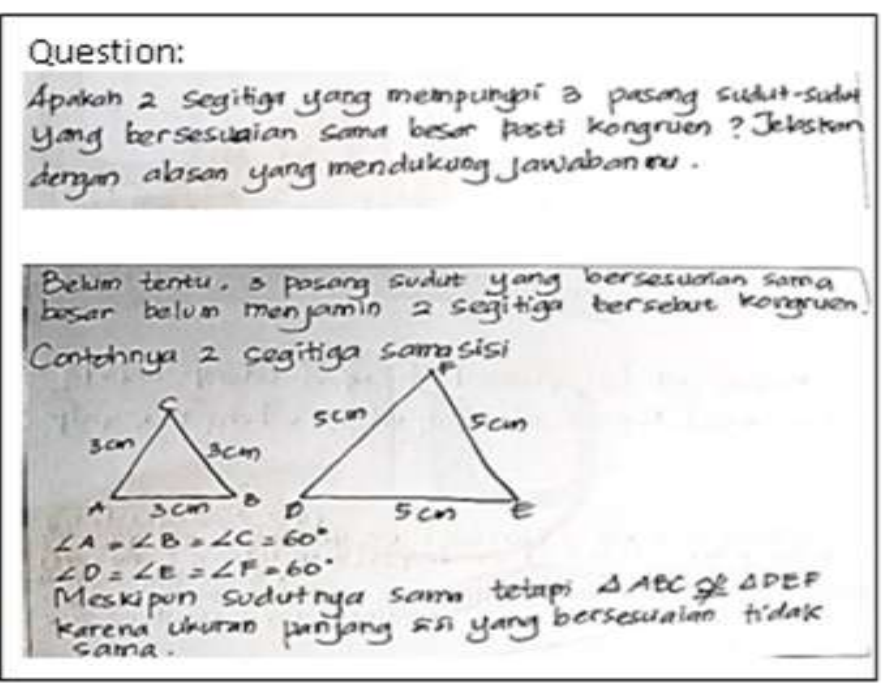

Fig 3. HOT task type $\mathrm{C}_{5}$ made by teacher

3.The task in Fig 3. demands a decision on the matter and decisions are taken as a whole that involves properties, examples of support or deniers, definitions and theorems on which the decisions are to be taken. In that case, students cannot only analyze from the nature and definition of congruence but also can provide examples that can support the answer so that the decision given is very reasonable.

Finally, the cognitive level $\mathrm{C}_{6}$ (creating) is the highest cognitive level of the HOT tasks that is rarely used by most teachers in making the tasks. The cognitive level of $\mathrm{C}_{6}$ is higher in degree of difficulty than other cognitive levels. On the cognitive level of $\mathrm{C}_{6}$, the brain is required to think of new something that can be used to solve the problem. But in this study there was none $(0.0 \%)$ math teachers who made the tasks with cognitive level of $\mathrm{C}_{6}$. This is supported by Iskandar (2015), the result of researched shown that the ability of chemistry teachers graduated from UNY in developing the tasks of final exam based on HOTS of $13.9 \%$ with $\mathrm{C}_{4}$ of $13.2 \%$; $\mathrm{C}_{5}$ of $0.7 \%$; and $\mathrm{C}_{6}$ of $0.0 \%$.

Not only the lower and higher order thinking tasks, in this study there are some tasks developed by math teachers who can not be categorized as LOT or HOT. The point is that the tasks created and developed by the teacher include content or context outside of junior math materials in curriculum.

The following of a task outside the content of junior math materials in general curriculum developed by math teachers.

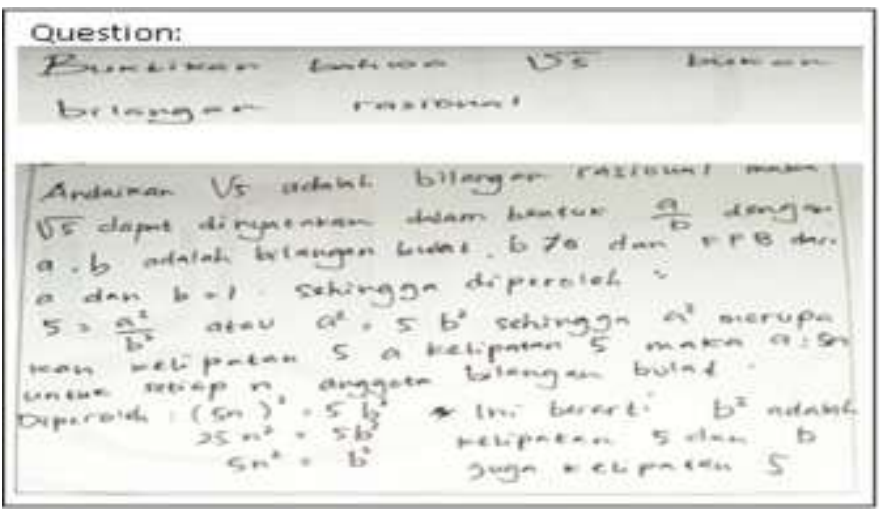

Fig 4. Task by teacher-made outside the junior content

From the task in Figure 4, the researcher does not enter into the high-level thinking categories. This is because the kind of task made by teacher is so high in rank from junior high school math in general. Although the junior high school curriculum contains root and rational number material, but the problem involving verification has not been so justified for junior high school students, let alone the material included in high class such as high school materials or lecture materials, except as a form of enrichment or for students who participate in a competition such as math olympics.

This indicates that some teachers understand that HOT is referred to as a difficult problem, a matter that has not been previously taught or a common problem given to children with higher abilities. Teachers can also be influenced by the higher 
order thinking that can be interpreted literally as a skill that is more than a student's ability in general. And this resulted in the teacher mistakenly making the HOT tasks.

It is not easy to create the tasks that require higher-order thinking skills. In shaping the quality of better students, these kinds of tasks must be developed by the teacher well and applied in the class. Teachers need to understand students' potential, problems and learning difficulties in order to implement effective teaching strategies and to produce meaningful learning among students. After the teachers find the difficult indicators, they might create new learning strategies that will be meaningful for providing the students' conceptual understanding towards the students regarding the difficult indicators. Multiple learning strategies might be applied in the learning process by adjusting the students' conditions, the materials or the indicators that will be studied and the drawbacks of each student (Retnawati et al., 2017).

The presentation of HOT tasks should be done first when students practice the questions or are combined in the Student Worksheet (LKS) for discovery and discussion activities, so that students are accustomed to working on HOT tasks. Teachers should try to develop their own HOT tasks or with their fellow teachers in deliberation of math teachers (MGMP) or teachers working group (KKG) at both subdistrict and district so that the quality of the tasks is included in the HOT category for mathematics learning of junior high school.

\section{CONCLUSION}

The ability of certified junior math teachers in developing HOT tasks in Kutai Timur district was very poor with the percentage gain of $20.10 \%$ with details of the problem that contains the ability to analyze $\left(\mathrm{C}_{4}\right)$ of $17.65 \%$, evaluate $\left(\mathrm{C}_{5}\right)$ of $2.45 \%$, and create $\left(\mathrm{C}_{6}\right)$ of $0.00 \%$.

The results of interviews from several math teachers found the factors that caused the low ability of math teachers to develop the HOT tasks are: (1) the HOT term is new something and even unknown by the teacher; (2) math teachers has difficulty to identified HOT tasks; (3) math teachers are not accustomed to giving the tasks based on higher order thinking in math learning in the classroom; and (4) at least or none references as well as examples of HOT tasks contained in textbooks.

Therefore, training is needed in developing HOTS characteristic problems for math teachers, so that the future is expected to have the ability and competence of teachers in developing learning tools based on higher order thinking skills.

\section{REFERENCES}

[1] L.W. Anderson, and D.R. Krathwohl, A Taxonomy for Learning, Teaching, and Assessing: A Revision of Bloom,s Taxonomy of Educational Objectives, Longman. New York, 2001.
[2] E. Apino, and H. Retnawati, "Developing Instructional Design to Improve Mathematical Higher Order Thinking Skills of Students Educational and Learning to Think," Journal of Physics: Conf. series 812 012100. http://iopscience.iop.org/1742-6596/812/1/012100, 2017.

[3] R. I. Arends, and A. Kilcher, Teaching for Student Learning Becoming an Accomplished Teacher, Routledge Taylor and Francis Group, New York, 2010.

[4] A. Budiman, and Jailani, "Pengembangan Instrumen Assesmen Higher Order Thinking Skill (HOTS) pada Mata Pelajaran Matematika SMP Kelas VIII Semester I," Jurnal Riset Pendidikan Matematika, vol. 1, no. 2, pp. 139-151, untuk Mengukur Kemampuan Berpikir Tingkat Tinggi Pokok Bahasan Barisan dan Deret Bilangan di Kelas IX Akselerasi SMP Xaverius Maria Palembang. Jurnal Pendidikan Matematika 1(2): 14-28, 2014.

[5] Peraturan Menteri Pendidikan Nasional Republik Indonesia Nomor 16 Tahun 2007 Standar Kualifikasi Akademik dan Kompetensi Guru. Jakarta.

[6] R.P.B. Ramirez, and M.S. Ganaden, Creative Activities and Students' Higher Order Thinking Skills, U. P. College of Education. Filipina, 2008.

[7] H. Retnawati, B. Kartowagiran, J. Arlinwibowo, and E. Sulistyaningsih, "Why Are the Mathematics National Examination Items Difficult and What is Teachers' Strategy to Overcome It?," International Journal of Instruction, vol. 10, no. 3, pp. 257-276, 2017.

[8] H. Retnawati, S. Hadi, and A.C. Nugraha, "Vocational High School Teachers' Difficulties in Implementing the Assessment in Curriculum 2013 in Yogyakarta Province of Indonesia," International Journal of Instruction, vol. 9, no. 1, pp. 33-48. www.e-iji.net, 2017.

[9] H. Retnawati, "The Comparison of Accuracy Scores on the Paper and Pencil Testing vs. Computer Based Testing," The Turkish Online Journal of educational Technology, vol. 14, no. 4, pp. 135-142, 2015.

[10] A. Rizta, Zulkardi, and Y. Hartono, "Pengembangan Soal Penalaran Model TIMSS Matematika SMP," Jurnal Penelitian dan Evaluasi Pendidikan, vol. 17, no. 2, pp. 230-240, 2013.

[11] P. Sahlberg. The Secret to Finland's Success: Educating Teacher. http://www.edpolicy.stanford.edu. 15 December 2016. 2010.

[12] A. Thomas, and G. Thorne. How to Increase Higher Order Thinking. http://goo.gl/rXxI5O. 31 October 2016. 2009.

[13] A. Woolfolk, Educational Psychology: Active Learning Edition, Yogyakarta: Pustaka Belajar, 2009.

[14] D. Iskandar, and Senam, "Studi Kemampuan Guru Kimia SMA Lulusan UNY dalam Mengembangkan Soal UAS Berbasis HOTS," Jurnal Inovasi Pendidikan IPA, vol. 1, no. 1, pp. 65-72, 2015.

[15] Jailani and Sugiman, Higher Order Thinking Skill (HOTS), Pengertian dan Peningkatannya Melalui PBL. In Desain Pembelajaran Matematika untuk Melatihkan Higher Order Thinking Skills. Heri Retnawati (Editor), Yogyakarta: UNY Press, 2016.

[16] A. Lewis, and D. Smith, Defining higher order thinking, Theory into Practice, 32(3): 131-137, 1993.

[17] Lewy, Zulkardi, and N. Aisyah, Pengembangan Soal, 2009. 